Page 19 - 30

\title{
Akuntabilitas Pengelolaan Keuangan Desa: Studi Kasus Gampong Harapan, Kota Lhokseumawe
}

\author{
Mustazir Ramli \\ Pemerintah Kota Lhokseumawe \\ mustazirramli@gmail.com
}

\begin{abstract}
The objective of research is to understand about mechanisms and design of accountability of financial management of villages and describes about the capacity of the government in the village of village financial management responsibilities. The design used is a case study with the object of research is Gampong Harapan Kota Lhokseumawe. Data collection techniques such as observation, interviews and documentation for later analysis using interactive data analysis methods, further to assure the validity of data used triangulation techniques.
\end{abstract}

Key Words: accountability mechanism, capacity government of Gampong.

\begin{abstract}
Abstrak
Tujuan dari penelitian ini adalah memahami bagaimana mekanisme dan bentuk akuntabilitas dalam pengelolaan keuangan desa serta dan menjelaskan bagaimana kapasitas pemerintah desa dalam mempertanggungjawabkan pengelolaan keungan keuangan. Desain yang digunakan adalah studi kasus dengan obyek penelitian adalah Gampong Harapan Kota Lhokseumawe. Teknik pengumpulan data yaitu observasi, wawancara dan dokumentasi untuk analisis nanti menggunakan metode analisis data interaktif, guna memastikan validitas data digunakan teknik triangulasi.
\end{abstract}

Kata Kunci: Mekanisme Akuntabilitas, Kapasitas Aparatur Gampong.

Diterima: 6 Januari 2017; Revisi: 10 Februari 20I7; Disetujui: 5 Maret 2017 


\section{PENDAHULUAN}

Disahkannya UU Desa (Undang-undang Nomor 6 Tahun 2014 Tentang Desa) telah menguatkan kembali bentuk pemberian otonomi dari pemerintah pusat kepada pemerintah desa (Widjaja, 2004: 12). Otonomi desa dapat diartikan sebagai hak, wewenang serta kewajiban yang dimiliki oleh pemerintah desa untuk dapat mengatur dan mengurus urusan pemerintahan sesuai dengan kepentingan masyarakatnya (PATTIRO, 20I5: 39). Salah satu hak desa yang dimaksud dalam UU Desa ialah hak untuk mengelola keuangan desa serta mendapatkan suntikan dana dari Anggaran Pendapatan dan Belanja Negara (Berita satu, 2016).

Namun, pemberian hak dan wewenang kepada pemerintah desa untuk mengelola keuangan desa belum seimbang dengan jumlah perangkat pemerintah desa yang memahami pengelolan keuangan serta pertanggungjawaban keuangan desa (Setyoko, 20lI). Kurangnya pemahaman akuntansi serta kemampuan yang dimiliki pemerintah desa dapat mengakibatkan kesalahan dalam pelaporan keuangan desa nantinya (Berita Satu, 20I5). Padalah kegiatan pelaporan keuangan sangatlah penting guna mewujudkan akuntabilitas dan kepercayaan publik dalam pengelolaan keuangan desa.

Menumbuhkan kepercayaan publik terhadap kinerja pengelolaan keuangan pemerintah sebagai wujud akuntabilitas merupakan hal penting dewasa ini (Dubnick, 2003). Akuntabilitas merupakan mekanisme yang harus dijalankan oleh pejabat publik untuk menjelaskan dan memastikan bahwa tindakannya telah sesuai, etis, bertanggung jawab (Scott, 2000). Studi terdahulu menujukkan bahwa organisasi pemerintah belum mampu mewujudkan akuntabilitas walupun sudah memiliki mekanisme yang jelas. Hal ini karena aparatur tidak mematuhi pelaksanaanya (Basri, 20I4).

KPK (Komisi Pemberantasan Korupsi) menemukan empat aspek potensi permasalah dalam pengelolaan keuangan desa, yakni aspek regulasi dan kelembagaan; aspek tata laksana; aspek pengawasan; dan aspek sumber daya manusia (KPK, 20I5). Persoalan lain yang sangat serius dalam pengelolaan keuangan desa adalah korupsi. Tindak korupsi sangat erat kaitanya dengan pengelolaan keuangan, korupsi juga berdampak pada buruknya akuntabilitas pejabat publik. Korupsi biasanya dapat terjadi akibat dari kurangnya pengawasan pada tingkat desa. (Rahman, 20II). 
Penelitian ini bertujuan untuk memahami bagaimana mekanisme dan bentuk akuntabilitas pengelolaan keuangan desa serta menggambarkan bagaimana kapasitas dari pemerintah desa dalam mempertanggungjawabkan pengelolaan keuangan desa dengan studi kasus pada Pemerintah Gampongl Harapan Kota Lhokseumawe. Pemilihan Gampong Harapan2 sebagai objek penelitian dikarenakan gampong ini pernah mendapatkan predikat terbaik atas pengelolaan keuangan berdasarkan penilaian dan evaluasi dari tim BPM (Badan Pemberdayaan Masyarakat) sebelum adanya UU Desa.

Selanjutnya, penelitian ini akan mendiskusikan secara singkat tentang teori dan penelitian terdahulu pada bagian Landasan Teori. Bagian ketiga merupakan penjelasan dari penggunaan metode penelitian. Selanjutnya bagian keempat yaitu temuan dilapangan serta diikuti dengan pembahasan. Terakhir, bagian kelima menyajikan kesimpulan penelitian, keterbatasan dan saran untuk studi lebih lanjut.

\section{KERANGKA TEORITIS}

Dalam Perwal 8/20I5 (Peraturan Walikota Lhokseumawe Nomor 8 Tahun 2015 Tentang Pengelolaan keuangan Gampong) dijelaskan bahwa pengelolaan keuangan gampong adalah keseluruhan kegiatan yang meliputi perencanaan, pelaksanaan, penatausahaan, pelaporan, hingga pertanggungjawaban keuangan. Ditambahkan pula bahwa pengelolaan keuangan gampong wajib memenuhi empat asas salah satunya adalah pengelolaan keuangan yang akuntabel. Sudarmaji (2009) menuturkan bahwa perwujudan pengelolaan keuangan yang akuntabel dapat dilihat dari kesesuaian antar perencanaan dan pertanggungjawaban keuangan.

Akuntabilitas hampir sama dengan responsibilitas, akan tetapi akuntabilitas lebih mensyaratkan bahwa pengambil keputusan harus berperilaku sesuai dengan mandat yang diterimanya secara etis dan bertanggungjawab (Budiarjo, 1998). Sejalan dengan hal tersebut, Mardiasmo (2002) menjelaskan bahwa akuntabilitas merupakan kewajiban untuk

\footnotetext{
${ }^{1}$ Nama lain dari desa di Provinsi Aceh, sesuai Qanun Nomor 5 Tahun 2003.

${ }^{2}$ Objek penelitian disamarkan berdasarkan permintaan Kepada desa/Keuchik.
} 
mempertanggungjawabkan keberhasilan atau kegagalan pelaksanaan misi organisasi dalam mencapai tujuan dan sasaran yang telah ditetapkan.

Konsep yang dikemukakan oleh J.B Ghartey (1987) dalam Sedarmayanti (2003) tentang akuntabilitas yaitu sebuah kegiatan untuk mencari jawaban terhadap pertanyaan yang berhubungan dengan pelayanan apa, siapa, kepada siapa, milik siapa, yang mana, dan bagaimana. Pertanyaan yang harus mendapatkan jawaban tersebut antara lain, apa yang harus dipertanggungjawabkan, mengapa pertanggungjawaban harus diserahkan, siapa yang bertanggungjawab terhadap berbagai kegiatan dalam masyarakat, apakah pertanggungjawaban sudah berjalan seiring dengan kewenangan yang dimiliki (LAN dan BPKP, 2007). Selanjutnya Dixon, et al, (2006) menyatakan bahwa akuntabilitas publik dapat diwujudkan kedalam dua bentuk. Pertama vertical accoutability (pertanggungjawaban kepada otoritas tingkat yang lebih tinggi atau pemberi tugas). Kedua horizontal accountability (pertanggungjawaban kepada masyarakat atau perwakilan masyarakat).

Beberapa penelitian terdahulu yang mengangkat isu akuntabilitas pada pemerintahan desa antara lain, penelitian Kloot dan Martin (200I) yang menemukan bahwa adanya perbedaan tingkat akuntabilitas antara perkotaan dan pedesaaan. Dijelaskan bahwa pada tingkat perkotaan kegiatan akuntabilitas merupakan hal yang penting untuk dilaksanakan sebagai upaya pemberian informasi kepada publik. Kondisi sebaliknya, akuntabilitas pada tingkat pedesaan kurang mendapat perhatian dari masyarakat. Hal ini dikarenakan budaya dari masyarakat desa yang cenderung mempercayai setiap tindakan yang telah dilakukan oleh pemerintah desa. Subroto (2008) yang meneliti tentang penerapan akuntabilitas pada pengelolaan ADD (Alokasi Dana Desa) menghasilkan bahwa penerapan akuntabilitas masih sebatas pertanggungjawaban fisik dilapangan, sedangkan pada sisi administrasi dinilai masih belum sepenuhnya dilakukan dengan aturan. Sejalan dengan hasil tersebut, Furqani (2010) dalam penelitiannya menyebutkan bahwa akuntabilitas pengelolaan keuangan desa masih sangat rendah karena kegiatan pertanggungjawaban tidak melibatkan masyarakat dan unsur legislatif desa/ BPD (Badan Permusyawaratan Desa). 
Persoalan buruknya sistem administrasi pada tingkat pemerintah desa bisa dikarenakan tidak adanya sanksi yang diberikan kepada pemerintah desa apabila terlambat dalam menyampaikan laporan keuangan desa (Hupe dan Hill, 2007). Ditambahkan bahwa kendala utama dalam keterlambatan penyerahan laporan keuangan desa dikarenakan kemampuan kerja street level bureaucrats yang sangat terbatas.

Padahal kemampuan administrasi merupakan komponen penting dalam melaksanakan tugas pemerintahan (Hupe dan Hill, 2007). Penelitian Setyoko (20II) mengenai implementasi akuntabilitas vertikal dan horizontal pada pengelolaan keuangan desa menemukan bahwa akuntabilitas pada pemerintahan desa belum berhasil. Padahal pemerintah kabupaten telah menyusun sistem dan mekanisme pelaporan keuangan namun ternyata dalam pelaksanaannya belum dapat dilakukan dengan baik oleh pemerintah desa.

Sebaliknya, Sudarmaji (2009) menemukan bahwa pengelolaan keuangan dan administrasi pada desa sudah baik. Pemerintah desa dinilai mampu menuangkan dokumen perencanaan keuangan dengan baik dan mempertanngunjawabkannya kedalam bentuk peraturan desa tentang pertanggunjawaban APBDes. Senada hal itu, Sulumin (20I5) menyatakan bahwa kegiatan pertanggung jawaban alokasi dana desa diberikan dengan baik kepada pemerintah daerah juga kepada masyarakat. Dijelaskan bahwa kepada pemerintah daerah dilakukan setiap bulan dan juga pada akhir tahun yang dilaksanakan secara struktural dari Kepala Desa kepada Camat, kemudian oleh Camat diteruskan Kepada Bupati. Sedangkan pertanggungjawaban kepada masyarakat d iberikan secara transparan dan langsung melaui kegiatan musyawarah desa.

\section{METODE}

Desain yang digunakan dalam penelitian ini adalah studi kasus yang merupakan bagian dari qualitative research (Basri, 20I4). Studi kasus digunakan untuk memahami tentang fenomena yang terjadi dalam pengelolaan keuangan gampong, kemudian mengakui dan menyelidiki hubungannya dalam akuntabilitas.

Pengumpulan data dalam desain studi kasus merupakan kegiatan yang dinamis dan dapat dilakukan dengan beragam cara (multi sources of data) diantaranya observasi, 
wawancara dan dokumentasi (Creswell, 2013). Observasi dilakukan untuk mendapatkan pengalaman tentang bagaimana proses pengelolaan keuangan desa di Gampong Harapan. Kemudian wawancara dilakukan secara indepth interview dengan informan yang telah ditentukan secara purposive sampling meliputi aparataur pemerintah Gampong Harapan dan Tim dari BPM sebagai pendamping pemerintahangampong, selanjutnya Tuha Peut dan Auditor juga di wawancarai guna mendapatkan pemehaman tentang fungsi pengawasan pada tingkat pemerintahan gampong. Wawancara dilakukan menggunakan pedoman wawancara semi terstruktur. Terakhir adalah dokumentasi untuk memudahkan penulis memperoleh dan menganalisa bahasa dan kata-kata tekstual dari informan (Bungin, 2007).

Analisis data menggunakan metode analisis data interaktif yang dicetuskan oleh Miles dan Huberman. Aktivitas analisis data dilakukan dengan tiga tahap, yaitu reduksi data, display data, dan penarikan kesimpulan/verifikasi (Sugiyono, 2014). Kemudian untuk meyakinkan validitas data yang diperoleh, peneliti menggunakan teknik trianggulasi sumber data dan trianggulasi metode untuk menguji validitas data yang diperoleh.

\section{HASIL DAN PEMBAHASAN}

Mekanisme dan Bentuk Akuntabilitas Pengelolan Keuangan desa di

\section{Gampong Harapan}

Mekanisme akuntabilitas pengelolaan keuangan desa di Gampong Harapan ditandai dengan adanya pemberian sumber pendanaan keuangan bagi Pemerintahan Gampong Harapan. Pemberian sumber keuangan ini haruslah dapat dipertanggungjawabkan dengan baik kepada Pemerintah Kota Lhokseumawe (vertical) dan kepada Tuha Peut juga masyarakat gampong (horizontal). Adapun hubungan antara pihak-pihak dalam mekanisme akuntabilitas pengelolaan keuangan desa i Gampong Harapan dapat digambarkan dengan ilustrasi dibawah ini: 


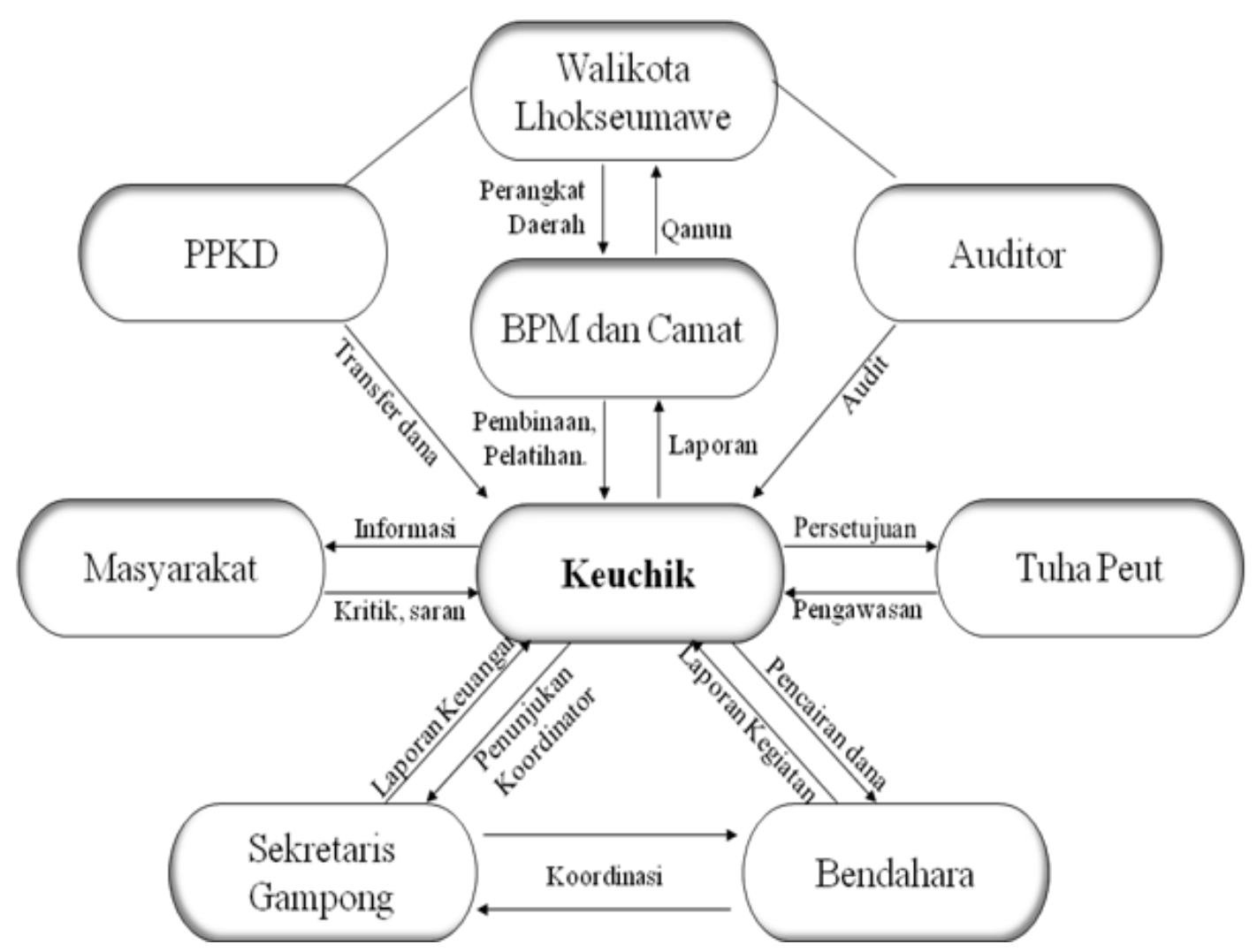

Gambar I : Mekanisme Akuntabilitas.

Walikota Lhokseumawe melalui perangkat daerah yaitu BPM (Badan Pemberdayaan Masyarakat) mempunyai kewajiban untuk memberi pembinaan dan pelatihan tentang pengelolaan keuangan desa kepada Keuchik serta perangkat gampong, pembinaan serta pelatihan diberikan agar pemerintah gampong dapat memahami dan mengerti bagaimana mengelola keuangan desa dengan baik dan mempertanggungjawabkannya sesuai ketentuan perundang-undangan. Sedangkan Camat memilki tugas memfasilitasi pemerintah gampong pada setiap kegiatan pengelolaan keuangan gampong. Dalam menjalankan pengelolaan keuangan gampong, Keuchik merupakan penanggungjawab utama. Akan tetapi dalam pelaksanaanya Keuchik dapat menunjuk sekretaris gampong sebagai koordinator pelaksana pengelolaan keuangan gampong. Kemudian sekretaris gampong dapat mengangkat seorang bendahara yang bertugas menatausahakan setiap kegiatan pengeluaran uang gampong.

Kegiatan pengelolaan keuangan gampong khususnya dalam perencanaan dan pertanggungjawaban harus melibatkan masyarakat dan lembaga legislatif gampong (Tuha Peut). Dalam perencanaan keuangan dijelaskan bahwa keterlibatan masyarakat gampong 
akan berguna dalam memberi kritik serta saran. Sedangkan Tuha peut akan berfungsi sebagai pengawas dan memberi persetujuan dalam kebijakan yang diputuskan oleh pemerintah gampong baik dalam perencanaan maupun dalam pertanngungjawaban keuangan.

Tabel I Media Akuntabilitas Gampong Harapan

\begin{tabular}{|c|c|c|}
\hline Vertikal & Media & Keterangan \\
\hline $\begin{array}{l}\text { Walikota } \\
\text { Lhokseumawe }\end{array}$ & $\begin{array}{l}\text { - Qanun } \\
\text { Pertanggungjawaban } \\
\text { APBG }\end{array}$ & $\begin{array}{l}\text { - Disampaikan pada akhir tahun } \\
\text { anggaran dan akhir masa jabatan } \\
\text { Keuchik. }\end{array}$ \\
\hline $\begin{array}{l}\text { Badan } \\
\text { Pemberdayaan } \\
\text { Masyarakat } \\
\text { (BPM),dan } \\
\text { Camat }\end{array}$ & $\begin{array}{l}\text { - Laporan realisasi triwulan } \\
\text { - Laporan realisasi tahunan }\end{array}$ & $\begin{array}{l}\text { - Disampaikan pertriwulan sebelum } \\
\text { pencairan dana lanjutan. } \\
\text { - Disampaikan pada akhir tahun } \\
\text { mencakup perkembangan } \\
\text { pelaksanaan dan penyerapan dana, } \\
\text { serta masalah yang dihadapi } \\
\text { gampong. }\end{array}$ \\
\hline Horizontal & - Media & - Keterangan \\
\hline Tuha Peut & $\begin{array}{l}\text { - Laporan } \\
\text { Pertanggungjawaban } \\
\text { APBG }\end{array}$ & $\begin{array}{l}\text { - Disampaikan untuk dibahas dan } \\
\text { disetujui hingga menjadi Qanun } \\
\text { Pertanggungjawaban APBG }\end{array}$ \\
\hline $\begin{array}{l}\text { Masyarakat } \\
\text { Gampong }\end{array}$ & $\begin{array}{l}\text { - Musyawarah Gampong } \\
\text { - Pengumuman Tertulis di } \\
\text { Kantor Keuchik. }\end{array}$ & $\begin{array}{l}\text { - Disampaikan secara lisan dalam } \\
\text { musyawarah. } \\
\text { - Disampaikan dengan cara } \\
\text { ditempel pada papan informasi } \\
\text { gampong/ meunasah. }\end{array}$ \\
\hline
\end{tabular}

Sumber : Data diolah, 2016

Kajian terdahulu oleh Dixon, et al (2006) akuntabilitas publik dapat memilki dua bentuk yaitu vertical accountability dan horizontal accountability. Secara vertikal kegiatan pertanggungjawaban Gampong Harapan kepada Walikota Lhokseumawe menggunakan Qanun pertanggungjawaban, sedangkan kepada BPM menggunkan laporan keuangan. Laporan keuangan diberikan secara triwulan dan tahunan sebagai sarana bagi pemerintah Kota Lhokseumawe untuk melakukan penilaian atas pengelolaan keuangan 
yang dilakukan pemerintah Gampong Harapan. Sementara itu, secara horizontal kegiatan pertanggungjawaban Gampong Harapan dilakukan kepada Tuha Peut yang melibatkan masyarakat gampong di dalam sebuah musyawarah gampong. Pertanggung jawaban juga dilakukan dengan cara menempelkan pengumuman agar memudahkan masyarakat mengakses informasi tersebut. Keterlibatan masyarakat gampong bertujuan untuk memberi legitimasi/ keabsahan atas segala kegiatan dalam pertanggungjawaban pengelolaan keuangan desa di Gampong Harapan. Media akuntabilitas vertikal dan akuntabilitas horizontal Gampong Harapan dirangkum dalam Tabel I.

Kapasitas Pemerintah Gampong Harapan dam

\section{Mempertanggungjawabkan Pengelolaan Keuangan Gampong.}

Dalam mempertanggungjawabkan pengelolaan keuangan desa, Pemerintah Gampong Harapan memiliki sumber daya manusia yang kompeten baik dalam bidang ilmu administrasi dan akuntansi. Dapat diketahui bahwa sekretaris Gampong Harapan merupakan seorang sarjana ilmu administrasi negara sedangkan bendahara gampong adalah seorang lulusan diploma akuntansi. Selain itu guna meningkatkan kapasitas pemerintah gampong dalam mengelola keuangan, Pemerintah Kota Lhokseumawe juga telah memberikan pelatihan agar kualitas aparatur gampong agar dalam mengelola dan mempertanggungjawabkan keuangan gampong dapat meningkat.

Lebih lanjut, Keberhasilan Pemerintah Gampong Harapan dalam mengelola keuangan dan mempertanggungjawabkannya merupakan wujud nyata dari intellectual ability dari seorang Keuchik. Berdasarkan hasil wawancara ditemukan bahwa kepemimpinan dari Keuchik Gampong Harapan dinilai sangat berperan dalam pencapaian akuntabilitas pengelolaan keuangan pada gampong ini. Kepemimpinan keuchik dalam memilih anggota kerja yang kompeten dan memiliki kesungguhan dalam bekerja akan membantunya dalam tim yang ada akan bekerja dengan baik karena satu tujuan dan model pemikiran.

\section{SIMPULAN}

Berdasarkan hasil dan pembahasan penelitian dapat diambil beberapa kesimpulan, Pertama, mekanisme akuntabilitas pengelolaan keuangan desa di Gampong 
Harapan sudah berjalan dengan baik. Kegiatan pelaporan dan pertanggungjawaban keuangan Gampong Harapan secara administrasi sudah diberikan sesuai dengan ketentuan. Laporan keuangan gampong seperti laporan realisasi dan laporan akhir penggunaan APBG telah disampaikan secara tepat waktu sebagai bentuk akuntabilitas vertikal mereka kepada Pemerintah Kota Lhokseumawe. Kemudian secara horizontal, pertanggungjawaban keuangan disampaikan di dalam forum musyawarah yang melibatkan Tuha Peut dan masyarakat gampong, selain itu pertanggungjawaban juga diumumkan pada papan informasi di kantor Keuchik.

Kedua, kapasitas Pemerintah Gampong Harapan dalam mempertangungjawabkan pengelolaan keuangan desa dirasakan sangat bagus. Kinerja Pemerintah Gampong Harapan dalam mempertangungjawabkan keuangaan desa dapat baik karena didukung oleh kualitas SDM dan banyaknya pelatihan yang diikuti oleh aparatur gampong. Sementara itu, sosok Keuchik sebagai pimpinan dinilai sangat berperan dalam mewujudkan akuntabilitas pengelolaan keuangan desa di Gampong Harapan.

\section{PUSTAKA ACUAN}

Basri, Hasan. Siti Nabiha. 2014. Accountability of Local Government: The Case Of Aceh Province, Indonesia. Jurnal Asia Pacific Journal of Accounting and Finance. Volume 3(I): I-I4.

Basri, Hasan. 20I4. Using Qualitative Research In Accounting And Management Studies: Not A New Agenda. Jurnal International Conference on Global Trends in Academic Research, June 2-3, 305-312.

Budiarjo, Miriam. 1998. Menggapai Kedaultan Untuk Rakyat. Bandung: Mizan.

Bungin, H. M. Burhan. 2007. Penelitian Kualitatif: Komunikasi, Ekonomi, Kebijakan Publik, dan IImu Sosial Lainnya. Edisi pertama Cetakan Ke-I. Jakarta: Kencana.

Creswell, John W. 2013. Research Desing: Pendekatan Kualitatif, Kuantitatif, dan Mixed. cetakan III. Yogyakarta: Pustaka Pelajar.

Darise, Nurlan. 2008. Akuntansi Keuangan Daerah (Akuntansi Sektor Publik). Jakarta: Indeks. 
Dixon. Ritchie, J. \& Siwale, J. 2006. Microfinance: Accountability from The Grassroots. Jurnal Accounting Auditing \& Accountability. Vol. 19, No. 3. 405-427.

Dubnick. 2003. Accountability and Ethics: Reconsidering The Relationships. International Journal of Organization Theory and Behavior. Vol. 6. No. 3. $405-$ $44 I$.

Hupe, P. \& Hill, M. 2007. Street-Level Bureaucracy and Public Accountability. Journal Public Administration, Vol. 85, No. 2: 219 - 229.

Kurniawan, Andri. 2010. Tugas dan Fungsi Keuchik dan Tuha Peut dalam Pemerintaan Gampong. Jurnal Dinamika Hukum UNSYIAH. Vol.I0 No.3.30I-3I4.

Kloot, L. \& Martin, J. 200I. Local Government Accountability: Explaining The Differences. Journal Accounting, Accountability and Performance, Vol. 7, No. I: 5 I 72.

Mardiasmo. 2002. Otonomi dan Manajemen Keuangan Daerah. Yogyakarta: Andi.

Miles, Matthew B., Huberman A. Michael. 1992. Analisis Data Kualitatif: Buku Sumber Tentang Metode-Metode Baru. Jakarta: UI Press.

Ndraha, Taliziduhu. 2005. Teori Budaya Organisasi. Cetakan Pertama. Jakarta: PT. Rineka Cipta.

Robert G, Murdick. Ross Joel E. 199I. Sistem Informasi Untuk Manajemen Modern. Penerjemah J.Djamil. Jakarta: Erlangga.

Scott. 2000. Accountability in The Regulatory State. Journal of Law and Society. Vol. 27. No. I. 38-60.

Sedarmayanti. 2003. Good Governance (Kepemerintahan yang baik) Dalam Rangka Otonomi Daerah. Bandung: Mandar Maju.

Sugiyono. 20I4. Metode Penelitian Kuantitatif Kualitatif dan R\&D. cetakan 20. Bandung: Alfabeta.

Sulumin, Hasman Husin. 2015. Pertanggungjawaban Penggunaan Alokasi Dana Desa Pada Pemerintahan Desa di Kabupaten Donggala. e-Jurnal Katalogis, Volume 3 Nomor I, 43-53. 
Widjaja, HAW. 2002. Otonomi Daerah dan Daerah Otonom. Jakarta: Rajawali Pers.

Widjaja, HAW. 2004. Otonomi Desa merupakan Otonomi yang Asli, Bulat, dan Utuh. Jakarta: Rajawali Pers. 